\title{
PELATIHAN: STRATEGI PEMBERDAYAAN KOPERASI DI ERA DIGITAL PADA KOPERASI KSB 210 SUMBER SURAKARTA
}

\author{
Irwan Christanto Edy ${ }^{1)}$ \\ Shandy Marsono ${ }^{2}$ ) \\ Supriyono ${ }^{3)}$ \\ STIE Adi Unggul Bhirawa Surakarta \\ irwan_aub@yahoo.co.id
}

\begin{abstract}
ABSTRAKSI
Koperasi merupakan tulang punggung perekonomian Indonesia. Dalam pasal 33 UUD 1945 dinyatakan bahwa "Perekonomian Indonesia disusun sebagai usaha bersama berdasarkan asas kekeluargaan". Koperasi Sumber Bahagia (KSB) 210 merupakan koperasi warga RT.02 RW 10 Kelurahan Sumber Surakarta yang sudah mengalami perkembangan cukup besar dan memberikan kontribusi kepada masyarakat. Permasalahan yang masih ada pada koperasi tersebut adalah pemberdayaan kemampuan usaha untuk meningkatkan pendapatan koperasi yang dapat meningkatkan kesejahteraan anggota. Selama ini koperasi hanya mengandalkan unit simpan pinjam kepada anggota koperasi, dimana struktur modal masih terbatas dan kemampuan manajemen masih konvensional. Jika koperasi ingin lebih berkembang, maka perlu adanya manajemen yang baik dan dapat mengoptimalkan peran media digital. Berdasarkan kajian situasi tim pengabdian pada masyarakat menyelenggarakan kegiatan penyuluhan dan pelatihan strategi pemberdayaan koperasi di era digital seperti pengenalan internet, facebook, instragram dan toko online untuk meningkatkan pelayanan dan pemasaran. Kegiatan ini memberikan hasil kepada anggota Koperasi KSB 210 Sumber Surakarta yaitu 1)memiliki pemahaman tentang internet untuk meningkatkan dan memberdayakan koperasi seperti wacana toko online, promosi melalui facebook, instagram, 2)memiliki pengetahuan dan ketrampilan tentang strategi pemberdayaan koperasi dengan media digital, 3)pelatihan bidang teknologi pada koperasi akan lebih optimal jika ada pendampingan secara berkala. Kegiatan ini membuka wacana lebih luas untuk memberdayakan koperasi melalui program pengyuluhan, pelatihan dan pendampingan di bidang teknologi internet.
\end{abstract}

Kata kunci : Koperasi, Pemberdayaan, Era Digital

\section{Pendahuluan}

Koperasi merupakan tulang punggung perekonomian Indonesia.Dalam pasal 33 UUD 1945 dinyatakan bahwa "Perekonomian Indonesia disusun sebagai usaha bersama berdasarkan asas kekeluargaan". Dalam penjelasan UUD 1945 disebutkan bahwa badan usaha yang sesuai dengan pasal tersebut adalah koperasi, sehingga koperasi ditempatkan sebagai sokoguru perekonomian Indonesia dan merupakan bagian integral perekonomian Indonesia. Dengan berbagai upaya tersebut diharapkan koperasi dapat tumbuh dan berkembang sejajar dengan pelaku ekonomi lainnya. Namun sampai saat ini koperasi lebih tertinggal dibanding dengan lembaga perekonomian lainnya. Penyebab ketertinggalan ini, karena banyaknya persoalan yang harus dihadapi oleh koperasi, diantaranya seperti yang dikemukakan oleh: Sukanto Reksohadiprodjo (1992: 234) yaitu "administrasi kegiatan-kegiatan koperasi belum memenuhi standar tertentu sehingga belum menyediakan data yang lengkap untuk pengambilan keputusan dari data statistik kebanyakan kurangmemenuhi kebutuhan". Selain itu, kendala perkembangan koperasi pada saat ini adalah manajemen, baik manajemen operasional, manajemen pemasaran produk dan tata kelola koperasi. Banyak koperasi yang belum memaksimalkan peran TIK khususnya media digital untuk memberdayakan koperasi. Koperasi Sumber Bahagia (KSB) 210 yang berlokasi di RT.02 RW.10 kelurahan Sumber Surakarta, merupakan koperasi yang cukup berkembang tetapi dalam pengelolaannya masih sangat konvnsional. Peran media belum Nampak pada koperasi tersebut, padahal media digital dapat menjadi saran yang efektif bagi koperasi untuk memasarkan produk atau unit usaha kepada 
masyarakat lebih luas, sehingga ada peningkatan laba dan akan meningkatkan kesejahteraan anggota . Berkaitan dengan hal tersebut maka Tim Pengabdian STIE AUB Surakarta melakukan kegiatan pengabdian pada masayarakat untuk pengurus dan anggota Koperasi KSB 210 Sumber dengan tujuan untuk membuka wacana pengurus dan anggota untuk memberdayaakan koperasi 210 ini dengan mengoptimalkan penggunaan media social seperti facebook, instagram, web internet dalam menjalankan fungsi fungsi manajemen seperti pemasaran dan operasional koperasi. Dalam kegiatan pengabdian pada masyarakat ini, yang menjadi rumusan masalah adalah : "Bagaimana memberdayakan koperasi di era digital dalam upaya peningkatan pendapatan untuk kesjahteraan anggota".

\section{Kajian Teori}

\section{Koperasi}

Pengertian Koperasi Pengertian koperasi ini dapat dibedakan menjadi 2 bagian, yaitu: pengertian umum dan menurut Undang-Undang Nomor 25 Tahun 1992 tentang koperasian. Pengertian secara umum koperasi adalah suatu perkumpulan yang beranggotakan orang-orang atau badan-badan hukum koperasi yang memberikan kebebasan masuk dan keluar sebagai anggota, dengan bekerjasama secara kekeluargaan para anggotanya. Berdasarkan pasal 1 Undang-Undang Nomor 25 Tahun 1992 tentang perkoperasian diberikan pengertian sebagai berikut: "koperasi adalah badan usaha yang beranggotakan orang-orang atau badan hukum koperasi dengan berlandaskan kegiatannya berdasarkan prinsip koperasi sekaligus sebagai gerakan ekonomi rakyat yang berdasarkan atas asas kekeluargaan. (Hendrojogi (2007;21)." Dengan penjelasan bahwa anggota koperasi sebagai pemilik dan sekaligus pengguna jasa koperasi, maka koperasi dapat diartikan sebagai mana yang diatur dalam Undang-Undang Perkoperasian Indonesia.

Koperasi diatur dalam UU No.12 tahun 1967 yang diperbaharui menjadi Undang-Undang No. 25 tahun 1992 yang menjelaskan tentang definisi koperasi. Koperasi menurut UU No. 12 tahun 1967 berbunyi: "Organisasi ekonomi rakyat yang berwatak sosial, beranggotakan orang- orang atau badan hukum koperasi yang merupakan tata susunan ekonomi sebagai usaha bersama berdasarkan azas kekeluargaan." Selain definisi koperasi menurut Hendrojogi $(2007 ; 22)$ mendefinisikan koperasi sebagai berikut: "Koperasi ialah suatu perkumpulan dari orang-orang yang atas dasar persamaan derajat sebagai manusia, dengan tidak memandang haluan agama dan politik secara sukarela masuk, untuk sekedar memenuhi kebutuhan bersama yang bersifat kebendaan atas tanggungan bersama." Dari beberapa pengertian koperasi tersebut, maka dapat disimpulkan bahwa apapun jenis koperasi yang didirikan di Indonesia mempunyai tujuan yang sama yaitu untuk kesejahteraan anggota pada umumnya dan masyarakat pada khususnya yang mengandung unsur demokrasi, sosial dan tidak semata-mata mencari keuntungan.

\section{Teknologi Internet}

Teknologi internet memiliki peran yang ganda, artinya internet sebagai teknologi dapat berlaku sebagai faktor lingkungan makro yang mempengaruhi kinerja perusahaan, tetapi teknologi internet juga dapat menjadi sumber daya (market resource), yang digunakan untuk meningkatkan kinerja pemasaran dan berdampak pada prospek perusahaan. Teknologi sebagai faktor lingkungan makro mengalami perkembangan yang sangat pesat. Perkembangan penggunan internet di Indonesia sangat cepat. Data dari internetworldstats.com (2014) menunjukan bahwa jumlah pengguna internet di Indonesia saat ini sekitar 71.190.000 yang tersebar di 34 propinsi di Indonesia. Dalam situs tersebut disebutkan bahwa Indonesia menempati peringkat ke empat sebagai pengguna internet terbesar di kawasan asia. Data tersebut, menggambarkan bahwa masyarakat Indonesia sudah mengenal dan sadar akan internet. Asosiasi Penyelenggara Jasa Internet Indonesia (APJII) mempublikasikan data bahwa media akses pengguna internet di dominasi oleh smartphone 96,6\%, telepon kabel 85\%, Jaringan nirkabel (WI-FI) 49\% dan sisanya TV Kabel dan satelit masing masing sebesar 11,4\% dan 3,4\% (APJII, 2012). Dari sumber data tersebut dikatakan bahwa mayoritas intensitas akses internet adalah sosial media 87,8\%, pencarian 
informasi (browsing) 68,9\% dan perdagangan online 0,1\%. Data Kementrian Komunikasi dan Informatika juga mengungkapkan bahwa pengguna internet tahun 2014 di Indonesia mencapai 82 juta orang dan Indonesia menduduki peringkat ke-4 terbesar di dunia dalam pemakaian sosial media yaitu facebook. Data tersebut mengungkapkan bahwa pengaruh internet di Indonesia sudah berkembang pesat jika dilihat dari pengguna.Korelasi pengaruh internet dalam bisnis menunjukan hubungan yang kuat. Beberapa bisnis telah mulai terkena dampak yang langsung dari teknologi internet. Bisnis angkutan (tranportasi) merupakan salah satu sektor bisnis yang terkena dampak langsung dari perkembangan teknologi internet, khususnya munculnya aplikasi mobile seperti Go-jek, Uber dan Grab Car. Bidang telekomunikasi, kalangan operator telekomunikasi mengalami penurunan bisnis voice dan sms, setelah muncul WhatsApps (WA) dan Line, banyak pengguna SMS yang beralih ke WA dan Line.

\section{Materi dan Metode}

Dengan permasalahan yang ada, maka tim pelaksana Pengabdian pada Masyarakat STIE-AUB Surakarta menawarkan penyelesaian dalam bentuk memberikan pelatihan ketrampilan pengelolaan koperasi di era digital. Adapun materi penyuluhan yang akan diberikan kepada para pengurus dan anggota koprasi 210 Sumber Surakarta adalah : 1) Penyuluhan tentang strategi pemberdayaan koperasi dengan media digital seperti toko online, facebook, twitter, website, instagram, 2)Penyuluhan dan Pelatihan membuat email, facebook, twiter, instagram, website melalui smartphone dan 3)Praktek pemasaran dengan smartphone untuk membuat facebook, instagram dan twiter. Dalam kegiatan pengabdian pada masyarakat ini, model kegiatan yang digunakan mengacu pada kerangka pemecahan masalah sebagai berikut:

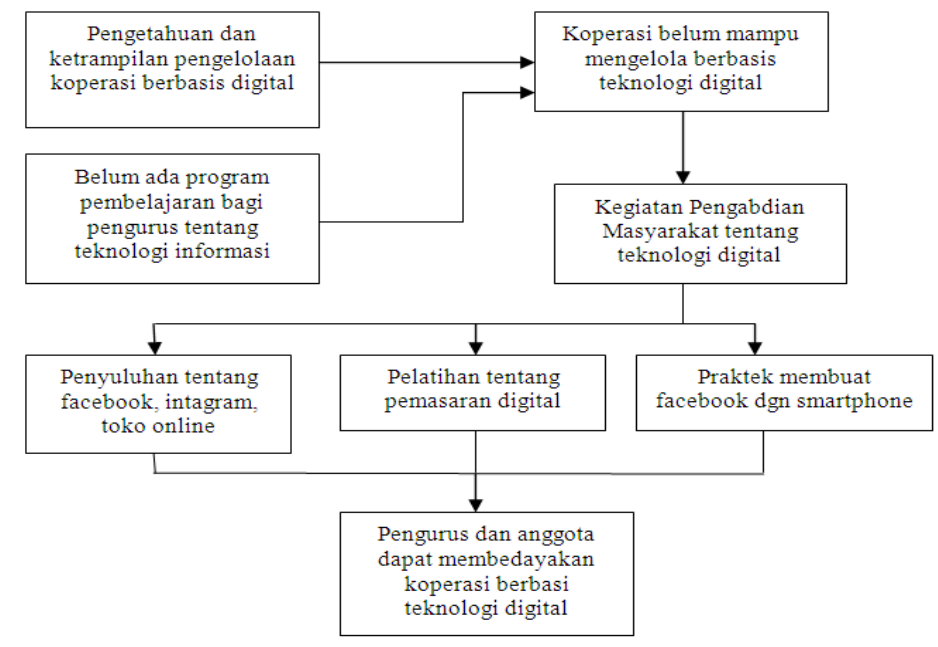

\section{Hasil dan Pembahasan}

Kegiatan Pengabdian pada Masyarakat (PKM) yang dilaksanakan dengan acara tatap muka dan praktek tentang pemberdayaan koperasi dengan teknologi internet. Pertemuan tatap muka dengan metode ceramah (penyuluhan), praktek, dilanjutkan Tanya jawab dan diskusi. Kegiatan ini dilaksanakan pada hari Sabtu tanggal 26 Januari 2018 dari pukul 17.00 sampai dengan selesai. Peserta kegiatan berjumlah sekitar 25 orang yang terdiri dari pengurus dan anggota koperasi KSB 210 Sumber yang tergabung pada warga RT 02 RW 10 Kelurahan Sumber Kecamatan Banjarsari Surakarta. Pelaksanan kegiatan PKM ini dilakukan oleh 3 (tiga) orang tim pengabdi dengan pokok bahasan yang disampaikan mengenai: 1) 
Pemberdayaan Koperasi, 2)Strategi pemberdayaan koperasi di era digital, 3)Membangun Manajemen dan Pemasaran berbasis Digital

Kegiatan yang diawali dengan memberikan ceramah atau penyuluhan oleh tim PKM, dan diskusi ini kemudian dilanjutkan demonstrasi. Dari kegiatan ini tampak bahwa pengurus dan anggota memang belum mengoptimalkan penggunaan teknologi digital untuk memberdayakan koperasi. Acara kemudian dilanjutkan sesi tanya jawab.

Berbagai pertanyaan diajukan secara antusias oleh para peserta dalam sesi tanya jawab. Secara garis besar inti dari pertanyaan para peserta adalah: 1)Langkah langkah dalam pemberdayaan koperasi, 2)Langkah-langkah penggunaan media digital. Program pengabdian pada masyarakat berupa pnyuluhan dan pelatihan pemasaran dengan media digital sperti toko online, facebook, instagram, yang sudah dilaksanakan ini diharapkan dapat menambah pengetahuan, keterampilan dan lebih percaya diri dalam menjalankan usahanya.Kegiatan ini memberikan pengaruh karena pengurus lebih bersemangat dan termotivasi untuk mengembangkan koperasi supaya tujuan koperasi baik untuk anggota maupun masyarakat dapat terlaksana dengan baik. Hasil pelatihan ini akan bermanfaat bagi pengurus dengan wacana yang baru. Hasil kegiatan pengabdian ini secara garis besar mencakup beberapa komponen sebagai berikut: 1)Keberhasilan target jumlah peserta kegiatan, 2)Ketercapaian tujuan kegiatan, 3)Ketercapaian target materi yang telah direncanakan, dan 4)Kemampuan peserta dalam penguasaan materi

Target peserta pelatihan seperti direncanakan sebelumnya adalah paling tidak 25 anggota dan pengurus koperasi. Dalam pelaksanaannya, kegiatan ini diikuti oleh 29 orang peserta. Dengan demikian dapat dikatakan bahwa target peserta tercapai 100\%. Angka tersebut menunjukkan bahwa kegiatan PKM dilihat dari jumlah peserta yang mengikuti dapat dikatakan berhasil/ sukses. Dari hasil lapangan diperoleh revisi model pemberdayaan koperasi adalah :

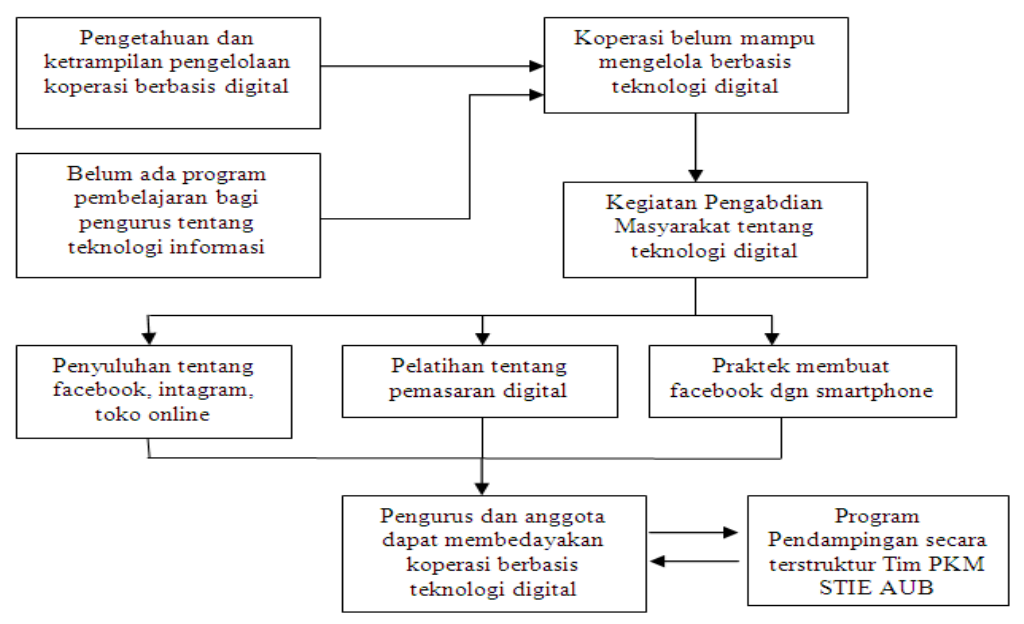

Ketercapaian tujuan kegiatan ini secara umum sudah baik, namun akan lebih optimal jika ada pendampingan secara berkala. Fokus dari pendampingan ini adalah menambahnya wawasan tentang strategi merintis dan mengembangkan usaha bagi pengurus dan anggota koperasi, baik secara umum maupun secara khusus tentang penggunaan teknologi internet untuk pemberdayaan koperasi.

Namun dilihat dari hasil kegiatan ini para peserta merasa termotivasi untuk memberdayakan koperasi dengan baik, maka dapat disimpulkan bahwa tujuan kegiatan ini dapat tercapai. Ketercapaian target materi pada kegiatan PKM ini cukup baik, karena materi kegiatan telah dapat disampaikan secara keseluruhan. Kemampuan peserta dilihat dari penguasaan materi masih kurang dikarenakan waktu yang singkat dalam penyampaian materi dan kemampuan para peserta yang berbeda-beda. Hal ini disebabkan jumlah materi yang banyak hanya disampaikan dalam waktu singkat sehingga tidak cukup waktu bagi 
para peserta untuk memahami dan mempraktekkan secara lengkap semua materi yang diberikan. Secara keseluruhan kegiatan keberhasilan dapat diukur dari kepuasan peserta setelah mengikuti kegiatan.

\section{Kesimpulan dan Saran}

1. Kesimpulan

Koperasi KSB 210 Sumber Surakarta merupakan koperasi yang masih menjalankan sistem manajemen konvensional. Beberapa permasalahan muncul di koprasi itu adalah permasalahan manajemen koperasi yang belum mengoptimalkan peran teknologi digital seperti toko online, facebook, website, instagram. Pngurus koperasi yang mengelola usahanya tanpa memiliki dasar pengetahuan maupun ketrampilan perihal manajemen modern seperti pemasaran dengan media digital seperti lewat facebook. Aspek-aspek manajemen usaha yang meliputi perencanaan keuangan, pengorganisasian, implementasi belum optimalkan penggunaan teknologi digital.

Berdasarkan kajian situasi tim pengabdian pada masyarakat menyelenggarakan kegiatan pelatihan pengelolaan koperasi khususnya dalam penggunaan teknologi digital. Dalam program pengabdian pada masyarakat ini tujuan yang tercapai adaah : 1)memiliki pemahaman tentang manajemen usaha berbasis digital, 2)memiliki pemahaman tentang teknologi digital. Kegiatan ini telah berjalan dengan baik dan mampu meningkatkan motivasi dan pemahaman pengrus tentang manajemen koperasi yang berbasis digital.

2. Saran

Dalam kegiatan pengabdian berikutnya perlunya pendampingan secara tehnis pada para pengurus dan anggota koperasi untuk diberi pelatihan menggunakan tehnologi digital seperti pembuatan toko online dan pemasaran digital lewat facebook, twitter, instagram an website.

\section{Daftar Pustaka}

ChaffeyDave, \& MayerRichard. (2009). Internet Marketing: Strategy, Implementation and Practice. Prentice Hall/Financial Times.

GaryArmstrong, WongVeronica, Philip Kotler, \& John Saunders. (2008). Principles of Marketing. Pearson Education Limited.

Jagdish N. Sheth. (2005). International E-Marketing: Opportunities and Issues. 61-65.

Meyliana. (2011). Analisa Strategi E-marketing dan Implementasinya pada Rental Company. 31-51.

Edilius, dan Sudarsono, 1993, Koperasi dalam Teori dan Praktik, Jakarta: PT. Rineka Cipta.

Firdaus, M. Dan Agus Edhi Susanto,2002, Perkoperasian: Sejarah, Teori, dan Praktek, Jakarta: Ghalia Indonesia.

Fuady, Munir, 2000, "Hukum Perseroan Terbatas", Jakarta: Ghalia.

Hariyanto, Gunawan, 2012, "Perlindungan Hukum Dana Simpanan Anggota Koperasi”,

Mizan. Hadikusuma, R.T.Sutantya Rahardja, 2000, Hukum Koperasi Indonesia., PT. Rajawali Pers, Jakarta.

Ismail, Ahmad Marzuki, 2005, Jati Diri Koperasi, Kim Guan Press Enterprise SDN. BHD. 